\title{
Synthesis and Crystal Structure of One Trinuclear di-n-butyltin(IV) Complex with Salicylaldoxime
}

\author{
Xu Hao-Long
}

Received: 13 June 2005/ Accepted: 19 September 2008/Published online: 7 October 2008

(C) The Author(s) 2008. This article is published with open access at Springerlink.com

\begin{abstract}
One trinuclear di- $n$-butyltin(IV) complex with salicylaldoxime $\left(o-\mathrm{HON}=\mathrm{CHC}_{6} \mathrm{H}_{4} \mathrm{OH}=\mathrm{HONZOH}\right),\left(\mathrm{Bu}_{2} \mathrm{Sn}\right)$ $\left(\mathrm{Bu}_{2} \mathrm{SnO}\right)\left(\mathrm{Bu}_{2} \mathrm{SnOH}\right)(\mathrm{ONZOH})(\mathrm{ONZO})$, has been synthesized and characterized by elemental analyses, IR spectrum, and single crystal X-ray diffraction. This complex is a small cluster displaying two unequivalent salicylaldoximate with one seven-coordinate pentagonalbipyramidal tin atom linked two five-coordinate trigonalbipyramidal tin atoms via a network of oxygen atoms by $\mathrm{Sn}-\mathrm{O}-\mathrm{Sn}$ bridges. The hydrogen bonds $\left(o-\mathrm{HON}=\mathrm{CHC}_{6} \mathrm{H}_{4}-\right.$ $\mathrm{O} . . \mathrm{H}-\mathrm{O})$ are observed in the complex. These hydrogen bonds include intramolecular hydrogen bonds and intermolecular hydrogen bonds. $\left(\mathrm{Bu}_{2} \mathrm{Sn}\right)\left(\mathrm{Bu}_{2} \mathrm{SnO}\right)\left(\mathrm{Bu}_{2} \mathrm{SnOH}\right)$ $(\mathrm{ONZOH})(\mathrm{ONZO})$ belongs to monoclinic: space group $P 2_{1} / \mathrm{n}$, with $a=12.2307(15) \AA, b=17.361(2) \AA, c=$ 20.976(3) ̊, $\beta=94.424(2)^{\circ}, V=4440.5(10) \AA^{3}, Z=4$, $D_{c}=1.500 \mathrm{~g} / \mathrm{cm}^{3}, \quad \mu(\mathrm{MoK} \alpha)=1.715 \mathrm{~mm}^{-1}, \quad F(000)=$ 2024, and final $R_{1}=0.0426, w R_{2}=0.1064$ for observed reflections $7779(I>2 \sigma(\mathrm{I}))$.
\end{abstract}

Keywords Diorganotin(IV) - Synthesis · Crystal structure

\section{Introduction}

Organotin complexes of oximido compound are a kind of interesting organotin oxo clusters and have attracted considerable attention during the last decades, In view of their unique multinuclear structural features as well as their

X. Hao-Long $(\square)$

Department of Chemistry and Chemical Engineering,

Weinan Teachers University, Weinan, Shaanxi 714000,

People's Republic of China

e-mail: xuhaolong@sina.com applications as biocides and in homogenous catalysis [1-5]. Great efforts have been devote to study multinuclear organotin complexes [6-9]. However, the establishment of a clear relationship between coordination structure of multinuclear tin cluster and different ligands has been very difficult owing to absolute lack of available crystal structure data.

Tin oxo compounds have been of the variety of geometries [10-14]. In the present work, we synthesized one new trinuclear di- $n$-butyltin(IV) complex with salicylaldoxime, $\left(\mathrm{Bu}_{2} \mathrm{Sn}\right)\left(\mathrm{Bu}_{2} \mathrm{SnO}\right)\left(\mathrm{Bu}_{2} \mathrm{SnOH}\right)(\mathrm{ONZOH})(\mathrm{ONZO})$. They were characterized by elemental analyses, IR spectrum, and single crystal X-ray diffraction.

\section{Experimental}

\section{Materials}

Di- $n$-butyltin oxide and salicylaldoxime were analytical grade and used without further purification. Ethanol and benzene were chemical reagent, and redistilling before using.

Physical Measurements

Elemental analyses for $\mathrm{C}, \mathrm{H}$, and $\mathrm{N}$ were determined on a Perkin-Elmer 2400 II analyzer. IR spectrum was obtained for $\mathrm{KBr}$ pellets on a Nicolet 460 spectrophotometer in the $4,000-400 \mathrm{~cm}^{-1}$.

Preparation of the Complex

$\left(\mathrm{Bu}_{2} \mathrm{Sn}\right)\left(\mathrm{Bu}_{2} \mathrm{SnO}\right)\left(\mathrm{Bu}_{2} \mathrm{SnOH}\right)(\mathrm{ONZOH})(\mathrm{ONZO})$

$\mathrm{Bu}_{2} \mathrm{SnO}(0.3734 \mathrm{~g}, 1.5 \mathrm{mmol})$ was dissolved in $15 \mathrm{ml}$ benzene and HONZOH $(0.1371 \mathrm{~g}, 1.0 \mathrm{mmol})$ was dissolved in 
Table 1 Crystal data and structure refinement parameters of the complex

\begin{tabular}{|c|c|}
\hline Complex & $\left(\mathrm{Bu}_{2} \mathrm{Sn}\right)\left(\mathrm{Bu}_{2} \mathrm{SnO}\right)\left(\mathrm{Bu}_{2} \mathrm{SnOH}\right)(\mathrm{ONZOH})(\mathrm{ONZO})$ \\
\hline CCDC & CCDC-274465 \\
\hline Color & Colorless \\
\hline Chemical formula & $\mathrm{C}_{38} \mathrm{H}_{66} \mathrm{~N}_{2} \mathrm{O}_{6} \mathrm{Sn}_{3}$ \\
\hline Formula weight & 1003.00 \\
\hline Temperature, $\mathrm{K}$ & $298(2)$ \\
\hline Wavelength, Å & 0.71073 \\
\hline Crystal system & Monoclinic \\
\hline Space group & $P 2_{1} / \mathrm{n}$ \\
\hline Volume, $\AA^{3}$ & $4440.5(10)$ \\
\hline \multirow[t]{3}{*}{ Unit cell dimensions } & $a=12.2307(15) \AA$ \\
\hline & $b=17.361(2) \AA$ \\
\hline & $c=20.976(3) \AA$ \\
\hline $\mathrm{Z}$ & 4 \\
\hline Density(calculated), $\mathrm{Mg} / \mathrm{m}^{3}$ & 1.500 \\
\hline Absorption coefficient, $\mathrm{mm}^{-1}$ & 1.715 \\
\hline Diffractometer, scan & Siemens SMART/CCD area, detector/ $\omega$-scans \\
\hline$F(000)$ & 2024 \\
\hline$\theta$ range for data collection & $2.00-25.03^{\circ}$ \\
\hline Reflections collection & 22671 \\
\hline Independent & $7779\left(R_{\mathrm{int}}=0.0400\right)$ \\
\hline Max. and min. transmission & 0.6545 and 0.5543 \\
\hline Refinement method & Full-matrix least-squares on $F^{2}$ \\
\hline Data/retraints/parameters & $7779 / 48 / 442$ \\
\hline Goodness of fit on $F^{2}$ & 1.005 \\
\hline Final $R$ indices $[I>2 \sigma(\mathrm{I})]$ & $R_{1}=0.0426, w R_{2}=0.1064$ \\
\hline$R$ indices (all data) & $R_{1}=0.0767, w R_{2}=0.1397$ \\
\hline Largest diff. peak and hole, $\mathrm{e} / \AA^{3}$ & 0.941 and -0.601 \\
\hline
\end{tabular}

$10 \mathrm{ml}$ ethanol, mixed two solution and then the mixture stirred for $4 \mathrm{~h}$. The resulting clear solution was rotary evaporated under vacuum to a small volume and was held at $6{ }^{\circ} \mathrm{C}$ for 5 days. Then the colorless crystal suitable for single crystal X-ray diffraction was obtained. IR $v(4,000-$ $\left.400 \mathrm{~cm}^{-1}\right)$ : 3455-3395 (NO-H), $2955(\mathrm{CH} 2), 686\left(\mathrm{Sn}_{3} \mathrm{O}\right)$, $632(\mathrm{Sn}-\mathrm{O}-\mathrm{Sn}), 586(\mathrm{Sn}-\mathrm{C}), 440(\mathrm{Sn}-\mathrm{N})$. Anal. Calcd for $\mathrm{C}_{38} \mathrm{H}_{66} \mathrm{~N}_{2} \mathrm{O}_{6} \mathrm{Sn}_{3}(\%)$ : C 45.50, H 6.63, N 2.79; Found: $\mathrm{C}$ 45.38, H 6.55, N 2.84 .

\section{X-ray Crystallography}

Single crystal of suitable size of the complex was mounted on Bruker Smart-1000 CCD diffractometer. Intensity data were collected with a graphite monochromated MoK $\alpha$ radiation $(\lambda=0.71073 \AA$ ) at $298(2) \mathrm{K}$. The structure was solved by directed method and the positions of the rest nonhydrogen atoms were determined from successive Fourier syntheses. The hydrogen atoms were placed in the geometrically calculated positions and allowed to ride on their respective parent atoms. The position and anisotropic parameters of all non-hydrogen atoms were refined on $F^{2}$ by full-matrix least-squares method using the SHELXL-97 program package. Crystal data and structure refinement parameters of the complex are summarized in Table 1. Selected bond lengths and angles are presented in Table 2.

\section{Result and Discussion}

The molecular structure and the packing diagram of the complex are depicted in Figs. 1, 2.

The $\mathrm{Sn}(1)$ is seven-coordinate in pentagonal bipyramidal geometry contaning two unequivalent salicylaldoximate, one oxygen atom and two $n$-butyl groups. Here, two salicylaldoxime are bidentate ligands coordinating to tin atom $\mathrm{Sn}(1)$ via the phenoxide oxygen atoms and the oxime nitrogen atoms respectively. The $\mathrm{O}(5), \mathrm{N}(1), \mathrm{N}(2), \mathrm{O}(1)$, $\mathrm{O}(3)$ take up the equatorial position, while $\mathrm{C}(19)$ and $\mathrm{C}(15)$ take up the axial sites. The mean deviation of five-coordinated atoms in the equatorial plane is $0.0394 \AA$, and the distance of $\operatorname{Sn}(1)$ from the plane is $0.0125 \AA$. 
Table 2 Selected bond lengths $(\AA)$ and angles $\left({ }^{\circ}\right)$ of the complex

\begin{tabular}{lllc}
\hline $\mathrm{Sn}(1)-\mathrm{O}(5)$ & $2.139(4)$ & $\mathrm{Sn}(1)-\mathrm{O}(1)$ & $2.254(5)$ \\
$\mathrm{Sn}(1)-\mathrm{N}(1)$ & $2.284(6)$ & $\mathrm{Sn}(1)-\mathrm{N}(2)$ & $2.623(6)$ \\
$\mathrm{Sn}(1)-\mathrm{O}(3)$ & $2.674(5)$ & $\mathrm{Sn}(2)-\mathrm{O}(5)$ & $2.037(4)$ \\
$\mathrm{Sn}(2)-\mathrm{C}(23)$ & $2.112(8)$ & $\mathrm{Sn}(2)-\mathrm{C}(27)$ & $2.125(8)$ \\
$\mathrm{Sn}(2)-\mathrm{O}(2)$ & $2.128(5)$ & $\mathrm{Sn}(2)-\mathrm{O}(6)$ & $2.163(5)$ \\
$\mathrm{Sn}(3)-\mathrm{O}(5)$ & $2.008(4)$ & $\mathrm{Sn}(3)-\mathrm{O}(6)$ & $2.142(5)$ \\
$\mathrm{Sn}(3)-\mathrm{O}(3)$ & $2.185(4)$ & $\mathrm{N}(2)-\mathrm{Sn}(1)-\mathrm{O}(3)$ & $65.48(16)$ \\
$\mathrm{O}(5)-\mathrm{Sn}(1)-\mathrm{O}(3)$ & $65.91(15)$ & $\mathrm{O}(1)-\mathrm{Sn}(1)-\mathrm{N}(1)$ & $76.34(19)$ \\
$\mathrm{O}(1)-\mathrm{Sn}(1)-\mathrm{N}(2)$ & $73.27(18)$ & $\mathrm{C}(19)-\mathrm{Sn}(1)-\mathrm{C}(15)$ & $162.4(3)$ \\
$\mathrm{O}(5)-\mathrm{Sn}(1)-\mathrm{N}(1)$ & $79.14(18)$ & $\mathrm{O}(5)-\mathrm{Sn}(2)-\mathrm{C}(27)$ & $117.0(3)$ \\
$\mathrm{O}(5)-\mathrm{Sn}(2)-\mathrm{C}(23)$ & $115.9(3)$ & $\mathrm{O}(2)-\mathrm{Sn}(2)-\mathrm{O}(6)$ & $156.74(18)$ \\
$\mathrm{C}(23)-\mathrm{Sn}(2)-\mathrm{C}(27)$ & $126.2(4)$ & $\mathrm{C}(23)-\mathrm{Sn}(2)-\mathrm{C}(27)$ & $126.2(4)$ \\
$\mathrm{O}(5)-\mathrm{Sn}(3)-\mathrm{C}(31)$ & $116.8(3)$ & $\mathrm{O}(5)-\mathrm{Sn}(3)-\mathrm{C}(35)$ & $114.3(3)$ \\
$\mathrm{C}(31)-\mathrm{Sn}(3)-\mathrm{C}(35)$ & $128.5(4)$ & $\mathrm{O}(3)-\mathrm{Sn}(3)-\mathrm{O}(6)$ & $152.50(18)$ \\
$\mathrm{Sn}(3)-\mathrm{O}(3)-\mathrm{Sn}(1)$ & $95.05(16)$ & $\mathrm{Sn}(3)-\mathrm{O}(6)-\mathrm{Sn}(2)$ & $101.5(2)$ \\
$\mathrm{Sn}(3)-\mathrm{O}(5)-\mathrm{Sn}(1)$ & $120.4(2)$ & $\mathrm{Sn}(3)-\mathrm{O}(5)-\mathrm{Sn}(2)$ & $110.9(4)$ \\
$\mathrm{Sn}(1)-\mathrm{O}(5)-\mathrm{Sn}(2)$ & $128.7(2)$ & & \\
\hline
\end{tabular}

The $\operatorname{Sn}(2)$ is five-coordinated in trigonal-bipyramidal geometry. The three atoms $[\mathrm{O}(5), \mathrm{C}(23), \mathrm{C}(27)]$ in the equatorial plane and the distance of $\operatorname{Sn}(2)$ from the plane is $0.1172 \AA$, while the two oxygen atoms $[\mathrm{O}(2), \mathrm{O}(6)]$ occupy the axial position. The sum of the angles of $\mathrm{O}(5)-\mathrm{Sn}(2)-$ $\mathrm{C}(23), \quad \mathrm{O}(5)-\operatorname{Sn}(2)-\mathrm{C}(27)$, and $\mathrm{C}(23)-\mathrm{Sn}(2)-\mathrm{C}(27)$ is $359.1^{\circ}$ which deviates from $360^{\circ}$ only $0.9^{\circ}$. The angle of $\mathrm{O}(2)-\mathrm{Sn}(2)-\mathrm{O}(6)$ is $156.74(18)^{\circ}$, which deviate from $180^{\circ}$. The $\mathrm{Sn}(3)$ atom is similar to the $\mathrm{Sn}(2)$ atom, existing in a five-coordinated environment. The three atoms $[\mathrm{O}(5)$, $\mathrm{C}(31), \mathrm{C}(35)]$ in the equatorial plane and the distance of

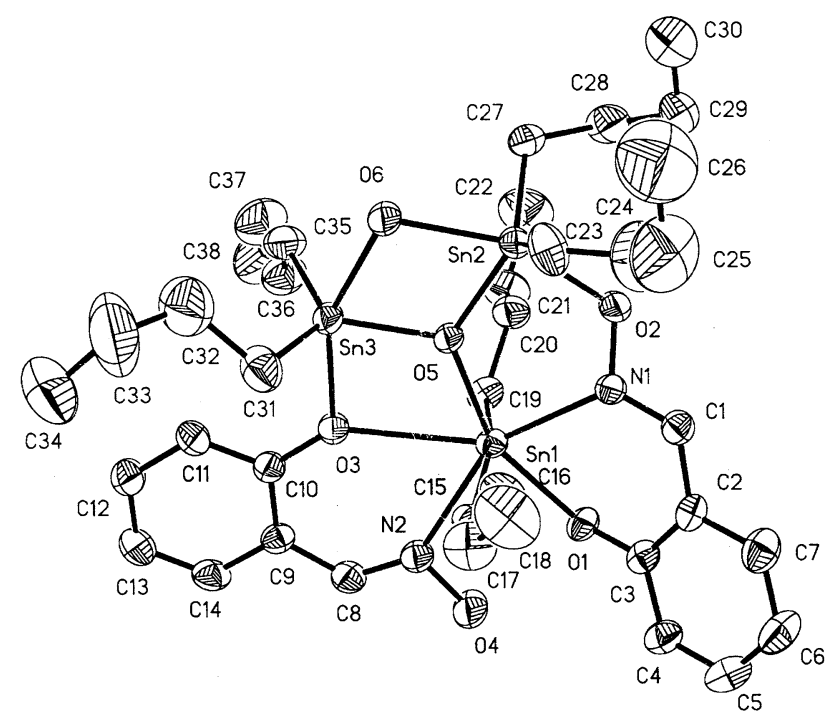

Fig. 1 The molecular structure of the complex showing $30 \%$ probability displacement ellipsoids

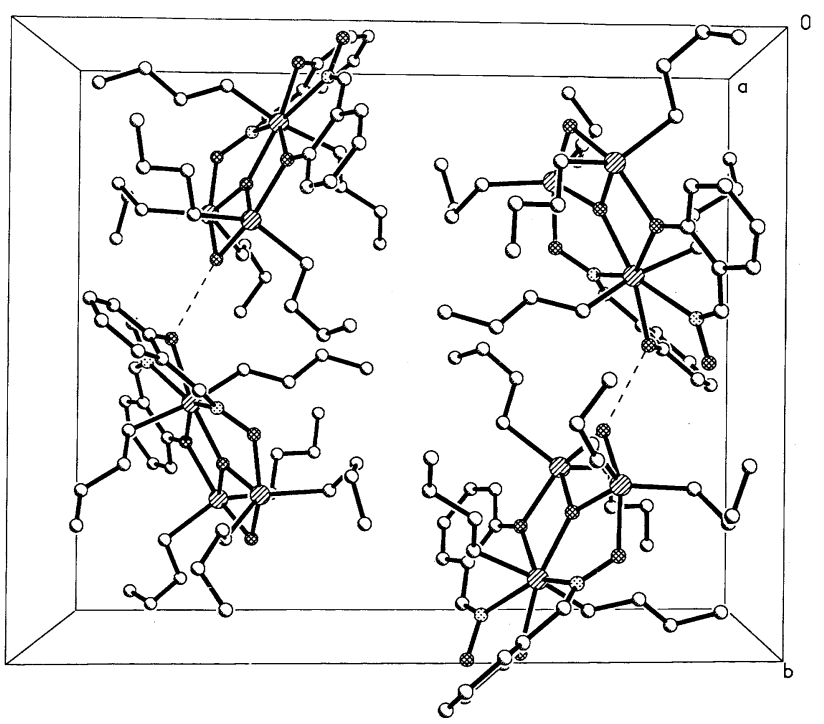

Fig. 2 Packing diagram of the complex showing the hydrogenbonded interactions as dashed line

$\mathrm{Sn}(3)$ from the plane is $0.0685 \AA$, while the two oxygen atoms $[\mathrm{O}(3), \mathrm{O}(6)]$ occupy the axial position. The $\mathrm{O}(3)$ coordinating to $\operatorname{Sn}(3)$ in axial situation is a $\mu_{2}$-phenolate oxygen atom, while $\mathrm{O}(2)$ coordinating to $\mathrm{Sn}(2)$ in axial situation is an oxime oxygen atom.

In the complex, three tin atoms are linked via a network of oxygen atoms by $\mathrm{Sn}-\mathrm{O}-\mathrm{Sn}$ bridges. $\mathrm{Sn}(1)-\mathrm{O}(3)$ bond length is longer than $\mathrm{Sn}(3)-\mathrm{O}(3)$ bond length. $\mathrm{Sn}(3)-\mathrm{O}(6)$ bond length is closed to $\mathrm{Sn}(2)-\mathrm{O}(6)$ bond length. The oxygen atom $\mathrm{O}(5)$ bond with all three tin atoms, The four atoms define one plane and the mean deviation of four atoms is $0.001 \AA$. The bond lengths of $\mathrm{Sn}(2)-\mathrm{O}(5)$ and $\mathrm{Sn}(3)-\mathrm{O}(5)$ are closed to each other but longer than $\mathrm{Sn}(1)-$ $\mathrm{O}(5)$.

When the crystal structure was solved, the $\mathrm{C}$ atoms of each butyl chain in the unit are rotationally disordered over two positions. The stacking geometry (Fig. 2) is such that the hydrogen-bonded linkage of adjacent units forming infinite chain. The $n$-butyl chains are loosely packed by van der Waals interactions, as reflected by the Ueq values of the $\mathrm{C}$ atoms, which increase on approaching the methyl termini.

Hydrogen bonds lie in the complex. These hydrogen bonds include intramolecular hydrogen bonds and intermolecular hydrogen bonds. The oxime oxygen atoms form intramolecular hydrogen bonds (NO-H...O) with the phenoxide oxygens atom $\mathrm{O}(1)$ which coordinated only to $\mathrm{Sn}(1)$, the hydroxy oxygen atom $[\mathrm{O}(6)]$ form intermolecular hydrogen bonds (O-H...O) with the phenoxide oxygens atom $\mathrm{O}(1)$ which coordinated only to $\mathrm{Sn}(1)$. Detailed hydrogen bonds of the complex are listed in Table 3. 
Table 3 Hydrogen Bond Interaction $\left(\AA{ }^{\circ}{ }^{\circ}\right)$ of the complex

\begin{tabular}{lllll}
\hline $\mathrm{D}-\mathrm{H} \ldots \mathrm{A}$ & $\mathrm{d}(\mathrm{D} \ldots \mathrm{H})$ & $\mathrm{d}(\mathrm{H} \ldots \mathrm{A})$ & $\mathrm{d}(\mathrm{D} \ldots \mathrm{A})$ & $<(\mathrm{DHA})$ \\
\hline $\mathrm{O}(4)-\mathrm{H}(4) \ldots \mathrm{O}(1)$ & 0.820 & 1.859 & 2.601 & 149.96 \\
$\mathrm{O}(6)-\mathrm{H}(4) \ldots \mathrm{O}(1)^{\#}$ & 0.930 & 1.927 & 2.823 & 161.30
\end{tabular}

Note: Symmetry transformations used to generate equivalent atoms

\# $-\mathrm{x}+1 / 2, \mathrm{y}-1 / 2,-z=1 / 2$

Acknowledgments We wish to thank Prof. Handong Yin for recording Crystal data and financial support Weinan Teachers University Special Foundation (No.07ykz031)

Open Access This article is distributed under the terms of the Creative Commons Attribution Noncommercial License which permits any noncommercial use, distribution, and reproduction in any medium, provided the original author(s) and source are credited.

\section{References}

1. Mokal VB, Jain VK, Tiekink ERTJ (1994) Organomet Chem 471:53. doi:10.1016/0022-328X(94)88106-5
2. Mercier A, Martins JC, Gienlen M, Biesemans M, Willem R (1997) Inorg Chem 36:5712. doi:10.1021/ic970866e

3. Molloy KC, Nowell IW (1987) J Chem Soc Dalton Trans 25:101. doi:10.1039/dt9870000101

4. Zubieta JA, Zuckermann JJ (1987) Inorg Chem 24:251

5. Otera J, kawada K, Yano T (2006) Chem Lett 18:225. doi: 10.1246/cl.1996.225

6. Bax A, Summers MF (1986) J Am Chem Soc 108:2093. doi: 10.1021/ja00268a061

7. Kayser F, Biesemans MF (1986) J Magn Reson 67:565

8. Keerler J, Clowes RT, Davis AL, Laue ED (1994) Methods Enzymol 239:145. doi:10.1016/S0076-6879(94)39006-1

9. Wrackmeyer B (1985) Annu Rep NMR Spectrosc 16:73

10. Tiekink ERT, Gielen M, Bouhdid A, Biesemans M, Willem R (1995) J Organomet Chem 494:247

11. Hasha DL (2001) J Organomet Chem 620:296. doi:10.1016/ S0022-328X(00)00785-3

12. Vatsa C, Jain VK, Das TK, Tiekink ERT (1990) J Organomet Chem 396:9. doi:10.1016/0022-328X(90)85187-4

13. Gielen M, Dalil H, Biesemans M, Mahieu B, De Vos D, Willem R (1999) Appl Organomet Chem 13:515. doi :10.1002/ (SICI)1099-0739(199907)13:7<515::AID-AOC875>3.0.CO;2-B

14. Danish M, Ali S, Mazhar M, Badshah A, Tiekink ERT (1996) Main Group Met Chem 19:121 